\title{
Glutaminase-Positive and Glutaminase-Negative Pyramidal Cells in Layer VI of the Primary Motor and Somatosensory Cortices: A Combined Analysis by Intracellular Staining and Immunocytochemistry in the Rat
}

\author{
Takeshi Kaneko, ${ }^{7}$ Youngnam Kang, ${ }^{2}$ and Noboru Mizuno' \\ Departments of 'Morphological Brain Science and 'Physiology, Faculty of Medicine, Kyoto University, \\ Kyoto 606-01, Japan
}

Pyramidal neurons in layer VI of the primary motor and somatosensory cortices were examined by a combined method of intracellular recording, biocytin injection, and immunocytochemistry using in vitro slice preparations of rat brain. Immunofluorescence staining revealed that biocytin-injected pyramidal cells in layer VI were separated into glutaminase (PAG)-immunopositive and PAG-immunonegative cells. Although the two groups of pyramidal cells showed no statistically significant differences in passive membrane properties and spike characteristics, a clear difference was found in spike afterpotentials. Ten of 12 PAG-positive pyramidal cells showed no or a small fast afterhyperpolarization (fAHP), whereas 10 of 11 PAG-negative pyramidal cells displayed a large fAHP. Depolarizing afterpotentials were observed only in PAG-positive pyramidal cells. Peroxidase staining for biocytin revealed that apical dendrites were shorter in PAG-positive pyramidal cells than in PAG-negative cells. In contrast, the arborization of basal dendrites was more developed in PAG-positive pyramidal cells than in PAG-negative cells. The main axons of all the pyramidal cells entered the subcortical white matter. The local axon collaterals of PAG-positive pyramidal cells were widely spread in the horizontal direction, whereas those of PAG-negative cells were distributed vertically along the dendritic tree. Since PAG is considered to be a marker of glutamatergic neurons in the cerebral cortex, the present results indicate that layer VI pyramidal cells are separated into glutamatergic and nonglutamatergic neurons that have different electrical properties and input-output organizations. Thus, cortical outputs from layer VI are suggested to use at least two distinct systems.

[Key words: glutaminase, pyramidal cell, layer VI, cerebral cortex, rat, intracellular staining, immunocytochemistry]

Layer VI of the cerebral neocortex, often called a "multiform" or "polynorphic" layer, is composed of various kinds of nonpyramidal neurons. Golgi impregnation studies have, however,

\footnotetext{
Received Apr. 17, 1995; revised Aug. 16, 1995; accepted Aug. 18, 1995.

We are grateful to Mr. Akira Uesugi and Ms. Miao-Li Zhang for photographic help. This work was supported in part by grants-in-aid from the Ministry of Education, Science and Culture of Japan (05267104, 05454658, 0560658).

Correspondence should be addressed to Prof. Noboru Mizuno at the above address.

Copyright $(\mathcal{O} 1995$ Society for Neuroscience $0270-6474 / 95 / 158362-16 \$ 05.00 / 0$
}

revealed that layer VI, particularly its superficial part (layer VIa), contains many pyramidal cells, which are characterized by an ascending apical dendrite and a skirt of basal dendrites with many spines and emit an axon from the lower part of the cell body (for review, see Tömböl, 1984). In some Golgi studies, it has been shown that layer VI pyramidal cells are separated into at least two groups with the height of apical dendrites (Lorente de Nó, 1949; Lund et al., 1979). One group of layer VI pyramidal cells has a long apical dendrite entering superficial layers II-IV, and the other possesses a short apical dendrite that does not extend beyond layer $\mathrm{V}$. A recent intracellular recording study using cat neocortical slices has shown that the firings of layer VI pyramidal cells are divided into those with and without depolarizing afterpotentials (DAPs), and that pyramidal cells showing DAPs have a shorter apical dendrite than pyramidal cells lacking DAPs (Kang and Kayano, 1994). These findings suggest that layer VI pyramidal cells of the neocortex are not a uniform entity.

L-Glutamate has been assumed to be a neurotransmitter released from corticothalamic axons of layer VI pyramidal cells (for review, see McCormick, 1992). Phosphate-activated glutaminase (PAG; L-glutamine amidohydrolase, EC 3.5.1.2), which catalyzes the hydrolysis of glutamine to glutamate, is considered to be a predominant synthesizing enzyme of transmitter glutamate, because transmitter glutaniate is mustly supplied from glutamine in the CNS (Bradford et al., 1978, 1989; Reubi et al., 1978; Hamberger et al., 1979a,b; Reubi and Cuénod, 1979; Reubi, 1980; Thanki et al., 1983; Ward et al., 1983; Szerb and O'Regan, 1984). In the cerebral cortex, PAG immunoreactivity is observed in many pyramidal neurons (Donoghue et al., 1985; Kaneko et al., 1987; Kaneko and Mizuno, 1988; Akiyama et al., 1990), whereas no PAG immunoreactivity is detected in GABAimmunoreactive neurons (Kaneko and Mizuno, 1994) or in nonpyramidal neurons inmunoreaclive for calbindin D28K (CB) or parvalbumin (PV) (Kaneko et al., 1992). In the mammalian neocortex, intense $\mathrm{CB}$ and $\mathrm{PV}$ immunoreactivities are observed in $12-20 \%$ and $70-74 \%$, respectively, of GABAergic neurons, and only occasionally colocalized in a GABAergic neuron (Celio, 1986; Demeulemeester et al., 1988, 1989; Hendry et al., 1989; Van Brederode et al., 1990, 1991). Thus, PAG immunoreactivity is considered to be a good marker for non-GABAergic, presumably glutamatergic cortical neurons, whereas $\mathrm{CB}$ and PV immunoreactivities are conjointly markers for the vast majority of GABAergic cortical neurons. 
In the present study, we investigated the electrophysiological, chemical, and morphological properties of pyramidal neurons in layer VI of the rat primary motor (MsI) and somatosensory (SmI) cortices by combining intracellular recording/staining technique with immunocytochemistry for PAG, CB, and PV. The present evidence shows that layer VI pyramidal cells are separated into two groups not only by electrical and morphological properties but also by chemical characteristics.

\section{Materials and Methods}

Wistar rats (Oriental Bioservice, Kyoto, Japan) weighing 150-200 gm were decapitated under ether anesthesia. The brains were quickly removed and cut frontally into $500-\mu \mathrm{m}$-thick slices on a Microslicer (Dosaka EM, Kyoto, Japan). The slices were preincubated at $20^{\circ} \mathrm{C}$ for $1-8$ hr in artificial cerebrospinal fluid (ACSF) saturated with $95 \% \mathrm{O}_{2}$ and $5 \% \mathrm{CO}_{2}$. The ACSF was composed of (in $\mathrm{mm}$ ) $124 \mathrm{NaCl}, 3.3 \mathrm{KCl}, 26$ $\mathrm{NaHCO}_{3}, 1.3 \mathrm{KH}_{2} \mathrm{PO}_{4}, 2.5 \mathrm{CaCl}_{2}, 1 \mathrm{MgSO}_{4}$, and $10 \mathrm{D}$-glucose. The slices were then transferred to an interface chamber, the temperature of which was maintained at $34-35^{\circ} \mathrm{C}$. Glass micropipettes were made with a puller (P-87; Sutter, Novato, CA) and filled with 3\% biocytin (Sigma, St. Louis, MO) dissolved in $2 \mathrm{M}$ potassium methylsulfate and $50 \mathrm{mM}$ Tris- $\mathrm{HCl}, \mathrm{pH} 7.4$. The electrode resistance was usually $100-200 \mathrm{M} \Omega$ The input signal was fed into a high-input impedance DC amplifier with an active bridge circuil (IR-183, Neurodata, New York, NY), and stored in a computer through an analog-digital converter (MacLab, AD Instruments, Castle Hill, Australia).

At the end of recording, the slices were fixed at $25^{\circ} \mathrm{C}$ for $20 \mathrm{hr}$ in $3 \%$ formaldehyde, $0.003 \%$ glutaraldehyde, and $0.1 \mathrm{M}$ sodium phosphate, pH 7. After cryoprotection with $30 \%$ sucrose in $10 \mathrm{~mm}$ phosphatebuffered $0.85 \%$ saline (PBS), the slices were further cut frontally into $30-\mu \mathrm{m}$-thick sections on a freezing microtome. In the following processes, each section was separately incubated in a well at room temperature, and the incubation was followed by rinses with PBS containing $0.3 \%$ Triton $\mathrm{X}-100$ and $0.02 \%$ sodium merthiolate (PBS-X). The sections were first soaked for $30 \mathrm{~min}$ in $2 \% \mathrm{H}_{2} \mathrm{O}_{2}$ in PBS to suppress endogenous peroxidase activity, and incubated for $30 \mathrm{~min}$ with $10 \%$ normal donkey serum in PBS-X. The sections were then incubated with a cocktail of 7-amino-4-methylcoumarin-3-acetic acid (AMCA)-conjugated avidin D (5 $\mu \mathrm{g} / \mathrm{ml}$; Vector, Burlingame, CA) and avidin-biotinylated peroxidase complex (ABC-Elite, Vector) in PBS-X. After incubation for at least $3 \mathrm{hr}$, the sections were observed under epifluorescence microscope Axiophot (Zeiss, Oberkochen, Germany) to search out biocytin-labeled cells. Into the well with a section containing biocytin-labeled cell bodies, $40 \mu \mathrm{g} / \mathrm{ml}$ anti-PAG mouse IgM (MAb-120; Kaneko et al., 1988), 1:2000-diluted anti-CB mouse IgG ascites (Sigma), and 1:8000-diluted anti-PV mouse IgG ascites (Sigma) were added. After overnight incubation, the sections were subsequently reacted with $25 \mu \mathrm{g} / \mathrm{ml}$ biotinylated horseradish peroxidase (Vector) in PBS-X. A fluorescein-conjugated anti-mouse IgM donkey antibody $(20 \mu \mathrm{g} / \mathrm{ml}$; Jackson, West Grove, PA) and a Texas red-conjugated anti-mouse IgG Fc donkey antibody $(10 \mu \mathrm{g} / \mathrm{ml}$; Jackson) were added into the well with the section containing biocytin-labeled cell bodies. After incubation for $1 \mathrm{hr}$, the intracellularly labeled cells were observed again under the epifluorescence microscope to determine whether the cells showed immunoreactivity for PAG, CB/PV, or neither. Fluorescence was observed under an appropriate filter set: AMCA, 360-370 nm excitation, 397$490 \mathrm{~nm}$ emission; fluorescein, $450-490 \mathrm{~nm}$ excitation, $515-565 \mathrm{~nm}$ emission; Texas red, $530-585 \mathrm{~nm}$ excitation, $\geq 615 \mathrm{~nm}$ for emission.

The peroxidase in the ABC bound to biocytin was finally developed for $30-60 \mathrm{~min}$ with $0.02 \%$ diaminobenzidine- $4 \mathrm{HCl}$ (DAB), $10 \mathrm{~mm}$ nickel ammonium sulfate, and $0.0001 \% \mathrm{H}_{2} \mathrm{O}_{2}$ in $50 \mathrm{~mm}$ Tris- $\mathrm{HCl}$, pH 7.6. The sections were mounted on a gelatin-coated glass slide, counterstained for Nissl with neutral red, dehydrated in ethanol series, cleared in xylene, and coverslipped. Recovered neurons were reconstructed onto a two-dimensional plane by using camera lucida with the aid of a drawing tube attached to a light microscope. The cytoarchitectonic areas and layers were mainly determined according to Zilles (1985) with adequate reference to Donoghue and Wise (1982) and Swanson (1992). Layer VIa, the superficial part of layer VI, was separated in Nissl stain from layer $\mathrm{V}$ by the lack of large neuronal cell bodies, and from layer VIb by the closely packed appearance of layer VIa neurons (Peters and Kara, 1985). The MsI cortex in the present study corresponded to Fr1 and Fr3 of Zilles (1985), and to AGl of Donoghue and Wise (1982). The
SmI cortex was composed of Par1, FL and HL of Zilles (1985), and nearly equal to SI of Donoghue and Wise (1982). The impalement of neurons was carried out mostly in Fr1 and Parl areas. Statistical data were analyzed by nonparametric methods, such as the two-tailed MannWhitney $U$ test and Fisher exact probability test (Siegel, 1956).

\section{Results}

The electrical activity of 55 layer VIa neurons, which were situated within $100 \mu \mathrm{m}$ from the section surface of the slices, was stably recorded in MsI and SmI cortices for at least 20 min with a resting membrane potential more negative than $-60 \mathrm{mV}$. Sixteen to nineteen $30-\mu \mathrm{m}$-thick sections were obtained from a 500 $\mu \mathrm{m}$-thick slice. The cell bodies of the recovered neurons were located between the 6th and 13th sections. After reconstruction of the soma and dendrites by camera lucida drawing, 23 spiny neurons were selected as pyramidal cells that had a prominent apical dendrite extending toward the cortical surface and a skirt of basal dendrites around the cell body. Other spiny neurons, such as "inverted pyramidal" cells, were not included in the pyramidal cells. The triple fluorescence study revealed that 12 of the 23 pyramidal cells were immunopositive for PAG, but the remaining 11 were immunonegative for PAG (Fig. 1). All the pyramidal cells showed no immunoreactivity for CB or PV, suggesting that all these neurons were non-GABAergic.

The distribution of PAG-negative and PV/CB-negative neurons was studied in the cerebral neocortex of perfusion-fixed brains by a double immunoperoxidase method. Figure 2 shows the distribution of PAG-positive and CB/PV-positive neurons in the MsI cortex. Since PAG immunoreactivity, which is located in the mitochondria of neuronal perikarya (Aoki et al., 1991), was detected as granular immunoreaction deposits, PAG-positive neurons were easily discriminatcd from $\mathrm{CB} / \mathrm{PV}$-positive neurons which displayed fairly homogeneous immunoreactivity (arrowheads in Fig. 2b). Many large- to medium-sized neuronal cell bodies showed intense PAG immunoreactivity among granular PAG immunolabeling in neuropil. Our previous double-immunofluorescence study revealed that no PAG immunoreactivity was found in CB- or PV-immunoreactive neurons in the rat neocortex (Kaneko et al., 1992). Thus, in terms of these immunoreactivities, the cerebral cortex contained three kinds of neurons: PAG-positive cells, CB/PV-positive cells, and PAG-negative and $\mathrm{CB} / \mathrm{PV}$-negative cells. Counterstaining with cresyl violet revealed that a number of neurons were immunonegative for $\mathrm{PAG}$ and $\mathrm{CB} / \mathrm{PV}$; arrows in Figure 2, $a$ and $b$, point to PAG-negative and $C B / P V$-negative neuronal cell bodies that are embedded in the background PAG immunoreactivity of neuropil. In particular, the superficial half of layer VI and deep portion of layer $\mathrm{V}$ contained many $P \wedge G$ negative and $C B / P V$-negative neurons (Fig. 2c). Although CB/PV-negative GABAergic neurons might be included in the PAG-negative and $\mathrm{CB} / \mathrm{PV}$-negative neurons, most $\mathrm{CB} / \mathrm{PV}$-negative GABAergic neurons in layers $\mathrm{V}-\mathrm{VI}$ are reportedly small bipolar neurons which are immunoreactive for vasoactive intestinal polypeptide and/or calretinin (Fuxe et al., 1977; Jacobowitz and Winsky, 1991; Kubota et al., 1994). Thus, at least a part of PAG-negative and CB/PV-negative neurons, particularly those with a large pyramidal-shaped perikarya in layers $\mathrm{V}$ and VI, are likely to be pyramidal cells.

\section{Electrical membrane properties}

No difference in the resting membrane potential was found between PAG-positive and PAG-negative pyramidal cells in layer VI (Table 1). The inpul resistance $\left(R_{N}\right)$ of PAG-positive pyramidal cells was lower than that of PAG-negative ones, but the 

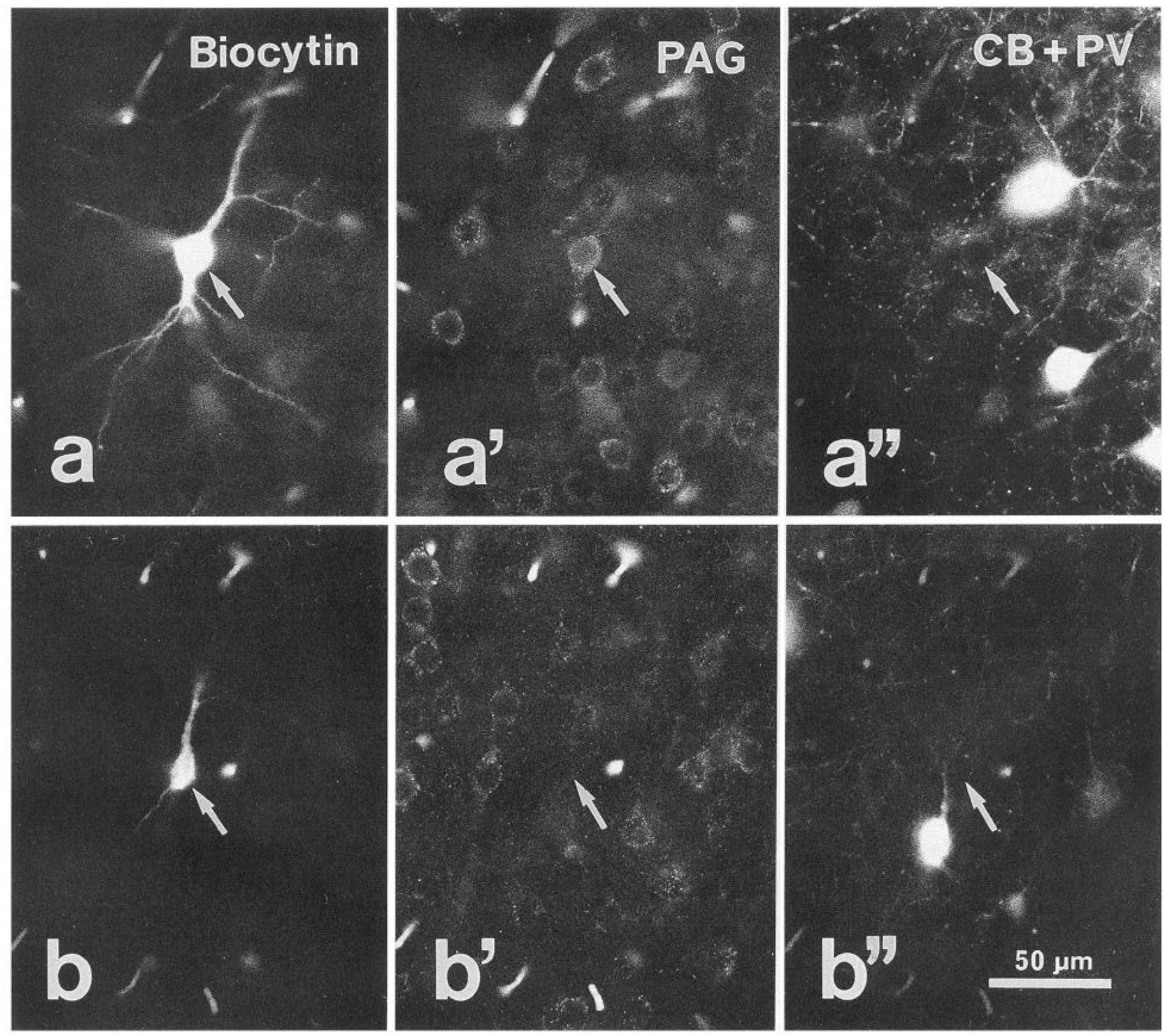

Figure 1. PAG and CB/PV immunoreactivities of intracellularly labeled pyramidal neurons. The three photomicrographs in each row were taken from a single site in layer VI of the cerebral cortex with the epifluorescence microscope under different excitations. Arrows indicate the biocytininjected neurons that were labeled with AMCA-conjugated avidin. PAG and CB/PV immunoreactivity was labeled with fluorescein and Texas red, respectively. The pyramidal neuron in " $a-a^{\prime \prime}$ displayed immunoreactivity for PAG but not for CB/PV. On the other hand, the neuron in $b-b$ " showed neither PAG nor CB/PV immunoreactivity.

difference was not statistically significant. Electrotonic time constants were measured by injecting $0.2 \mathrm{msec}$ depolarizing pulses. Potential decay from $1 \mathrm{msec}$ to $50 \mathrm{msec}$ after the current injection was mostly well fitted with a double exponential model. Neither membrane constant $\left(\tau_{m}\right)$ nor the first equalizing time constant $\left(\tau_{1}\right)$ was significantly different between PAG-positive and PAG-negative pyramidal cells. However, the electrotonic length of PAG-positive pyramidal neurons was shorter than that of PAG-negative neurons at the border of statistical significance $(p=0.05)$. Neither rheobase nor spike characteristics (height, rise time, and width) were significantly different between PAGpositive and PAG-negative pyramidal cells. The spike width of PAG-positive neurons, however, showed a tendency to be wider than that of PAG-negative ones.

Action potentials in neocortical pyramidal cells are usually followed by a fast afterhyperpolarization (fAHP) showing a peak within milliseconds after single spikes, and the succeeding me- dium-range AHP (mAHP) displaying a peak within tens of milliseconds after spikes (Schwindt et al., 1988). AHPs in layer VI pyramidal cells were examined by using short depolarizing pulses of 2-10 msec duration as follows (Fig. 3): First, an action potential was evoked by injecting a threshold depolarizing current pulse (trace $\mathrm{x}$ in Fig. $3 a_{l}, b_{l}$ ). Then, the subthreshold response (trace y) evoked by the same current pulse from a slightly hyperpolarized level $(0.05-0.1 \mathrm{nA}$ negative from trace $\mathrm{x})$ was subtracted from trace $\mathrm{x}$ to reveal active components that were accompanied by the action potential (trace $x-y)$. The subtraction was carried out at the resting (Fig. $3 a_{l}, b_{t}$ ), continuously depolarized (Fig. $3 a_{2}, b_{2}, \geq-60 \mathrm{mV}$ ), and continuously hyperpolarized potentials (Fig. $3 a_{3}, b_{3}, \leq-85 \mathrm{mV}$ ). The subtraction technique showed that there were at least two types of AHPs. One type of AHPs showed only one prominent peak which was in the range of the fAHP (Fig. $3 a_{l}, a_{2}$ ). Another type of AHPs was composed of no or a less prominent fAHP and a subsequent 

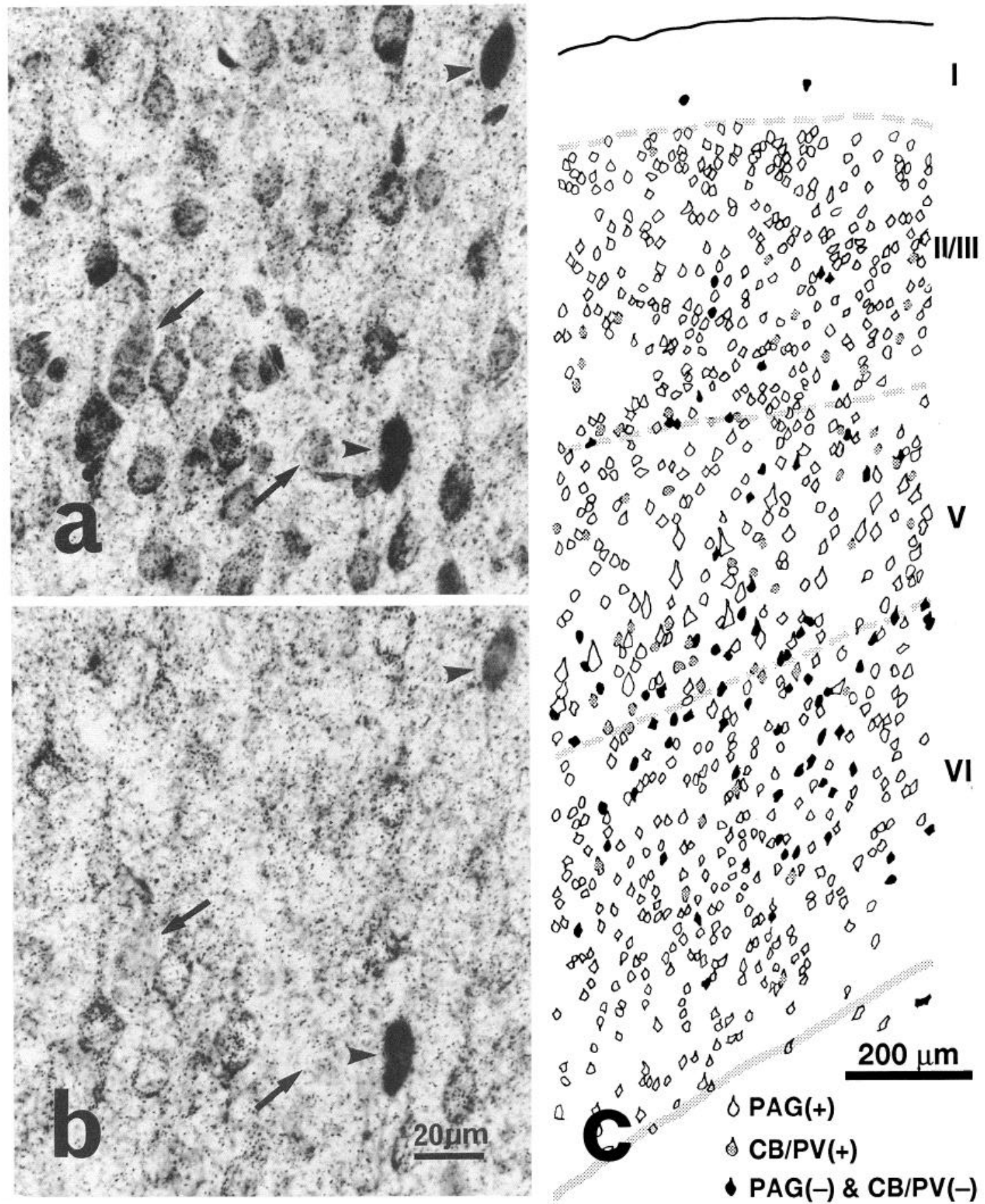

Figure 2. Distribution of PAG-positive and PAG-negative neurons in the rat MsI cortex. Frontal 20- $\mu$ m-thick sections prepared from perfusionfixed brains (Kaneko et al., 1989) were doubly immunostained for PAG and CB/PV with DAB as a chromogen. The sections were incubated with $10 \mu \mathrm{g} / \mathrm{ml}$ of anti-PAG mouse IgM, 1:5000-diluted anti-CB mouse IgG, and 1:20,000-diluted anti-PV mouse IgG. PAG was first stained by the ABC method with a biotinylated anti-mouse IgM antibody (Kaneko and Mizuno, 1988), and CB/PV was then stained by the PAP method with an unlabeled anti-mouse IgG antibody (Sternberger, 1979). $a$, The sections were counterstained with cresyl violet after the immunostaining, and photographed under conventional green light. $b$, The same region was photographed under the light through a filter with a band path around 450 $\mathrm{nm}$ to suppress the color of the counterstaining. Arrows in $a$ and $b$ indicate PAG-negative and CB/PV-negative neurons, and arrowheads point to CB/PV-positive GABAergic cells. $c$, Three kinds of neurons are plotted in the MsI cortex. Note that PAG-negative and CB/PV-negative neurons were most densely distributed in the superficial half of layer VI and deep part of layer V.

mAHP that was larger than the fAHP (Fig. $3 b_{2}$ ). In a few cells examined, the depth of the fAHP was almost the same (within $1 \mathrm{mV}$ difference) as that of the mAHP. When a slowly depolarizing "hump" followed the action potential at the resting potential (Fig. $\left.3 b_{l}\right)$, continuously depolarizing current $(\geq-60 \mathrm{mV})$ was used to examine AHPs (Fig. $3 b_{2}$ ) because a large portion of the hump could be inactivated above $-60 \mathrm{mV}$ as is described below.

Ten of 11 PAG-immunonegative pyramidal cells displayed a prominent fAHP without an mAHP peak, whereas twelve PAGimmunopositive and one PAG-negative pyramidal cells showed no or a small fAHP followed by an mAHP peak (Table 2). Two 
Table 1. Electrophysiological properties of layer VIa pyramidal cells

\begin{tabular}{|c|c|c|c|}
\hline & $\begin{array}{l}\text { PAG } \\
\text { positive }\end{array}$ & $\begin{array}{l}\text { PAG } \\
\text { negative }\end{array}$ & $\begin{array}{l}p(U \\
\text { test })\end{array}$ \\
\hline Number of cells & 12 & 11 & - \\
\hline Resting potential $(\mathrm{mV})$ & $-68 \pm 3$ & $-68 \pm 5$ & 0.88 \\
\hline$R_{N}(\mathrm{M} \Omega)$ & $108 \pm 45$ & $142 \pm 72$ & 0.23 \\
\hline$\tau_{m}(\mathrm{msec})$ & $13.8 \pm 4.0$ & $11.5 \pm 5.5$ & 0.18 \\
\hline$\tau_{1}(\mathrm{msec})$ & $1.48 \pm 1.18$ & $2.19 \pm 2.01$ & 0.31 \\
\hline Electrotonic length ${ }^{a}$ & $1.09 \pm 2.04$ & $1.52 \pm 2.37$ & 0.052 \\
\hline Rheobase (nA) & $0.24 \pm 0.10$ & $0.17 \pm 0.10$ & 0.13 \\
\hline Spike height (mV) & $94 \pm 13$ & $92 \pm 8$ & 0.80 \\
\hline Spike rise time (msec) & $0.44 \pm 0.07$ & $0.42 \pm 0.04$ & 0.45 \\
\hline $\begin{array}{l}\text { Spike width, } 1 / 2 \text { ampl. } \\
\text { (msec) }\end{array}$ & $0.82 \pm 0.13$ & $0.76 \pm 0.09$ & 0.15 \\
\hline $\begin{array}{l}\text { Spike width, at base } \\
\text { (msec) }\end{array}$ & $1.58 \pm 0.19$ & $1.45 \pm 0.26$ & 0.17 \\
\hline $\begin{array}{l}\text { Afterpotential level } \\
(\mathrm{mV}) \\
3.3 \mathrm{msec} \text { after spike }\end{array}$ & & & \\
\hline $\begin{array}{l}\text { onset } \\
29 \text { mscc after spikc }\end{array}$ & $2.6 \pm 6.0$ & $-4.8 \pm 5.6$ & 0.016 \\
\hline onset & $-2.4 \pm 2.3$ & $-4.0 \pm 3.5$ & 0.32 \\
\hline
\end{tabular}

Data are nlean $1 \mathrm{SD}$.

"The electrotonic length of an equivalent sealed-end cylinder was estimated by expression $\pi / \sqrt{\tau_{r m} / \tau_{1}-1}$

"Measured from the baseline prior to the spike in trace $x-y$ of Figure 3, which had a single action potential evoked by a short depolarizing pulse from the resting potential.

of the 12 PAG-positive pyramidal cells cxpressed an fAHP and an mAHP of comparable depth (within $1 \mathrm{mV}$ difference). The difference in the shape of AHPs between PAG-positive and PAG-negative pyramidal cells was highly significant in the Fisher test $(p<0.0001$; Table 2$)$. In the cases that showed peaks for the fAHP $(n=18)$ and mAHP $(n=13)$, the peaks of the fAHP and mAHP were observed at $3.3 \pm 1.0$ and $29 \pm 9 \mathrm{msec}$ (mean $\pm \mathrm{SD}$ ), respectively, from the onset of spikes. Afterpotential level at $3.3 \mathrm{msec}$ from the spike onset was positive in PAG-positive pyramidal cells and, in contrast, negative in PAGnegative cells ( $p<0.02$; Table 1 ), although this data may be complicated with several factors, such as depolarizing humps and the level of resting potentials. No significant difference in the afterpotential at $29 \mathrm{msec}$ from the spike onset was found between PAG-positive and PAG-negative pyramidal cells, indicating that the difference in the shape of AHPs between the two groups of pyramidal cells was attributed mainly to the difference in the fAHP.

A DAP was, in the present study, defined by a depolarizing small wave that followed each action potential in the midst of a long-duration depolarizing current pulse (Fig. $4 a_{2}$ ). This definition was used because the DAP could be differentiated from the low-threshold spike (LTS) that was seen only at the onset of depolarizing current pulses. Clear DAPs were observed in five pyramidal cells, all of which were immunoreactive for PAG ( $p$ $<0.05$; Table 2).

A slowly depolarizing hump following an action potential was evoked in nine PAG-positive and three PAG-negative pyramidal cells by a short depolarizing current pulse at the resting membrane potential (Table 2, Fig. $3 b_{l}$ ). This kind of hump was also observed with or without action potentials at the onset of longduration depolarizing pulses (Fig. 5). All the humps observed in the present study could be largely suppressed by continuous depolarization at $-60 \mathrm{mV}$ and over. On the contrary, all the pyramidal cells examined showed a clear depolarizing hump when continuously hyperpolarized below $-85 \mathrm{mV}$ (Fig. $3 a_{3}, b_{3}$ ). These findings suggest that the hump was mainly composed of the LTS (Jahnsen and Llinás, 1984a,b), though the DAP was, in some cells, likely to participate in the hump associated with action potentials (Fig. 5). A rebound hump, a depolarizing overshoot at the offset of a long-duration hyperpolarizing current pulse, was observed in all the pyramidal neurons (Table 2). However, rebound spikes superimposed on the rebound hump (Fig. $4 b_{2}$ ) were observed only in three pyramidal cells.

Initial phasic responses of action potentials to long-duration positive current pulses were recognized in all the pyramidal cells, some of which showed initial doublet or triplet spikes (Fig. $4 a_{I}$ ) and the other displayed initial rapid adaptation of the spike frequency (Fig. $4 a_{2}$ ). The phasic responses were neither repeated during a long depolarizing current pulse, evoked in an all-ornone manner, nor followed by large long-duration AHPs. Thus, all the layer VI pyramidal cells were considered to belong to the "regular spiking" class described by McCormick et al. (1985). Nine PAG-positive and three PAG-negative pyramidal cells showed doublet or triplet spikes at the onset of long-duration depolarizing pulses (Table 1). Initial doublet/triplet spikes ap peared to be associated with slow depolarizing humps, because 10 pyramidal cells in the present study showed both initial doublet/triplet spikes and depolarizing humps $(p=0.0033$ by the Fisher test).

Spike frequency adaptation in the late phase of a long-duration positive current pulse was observed in the majority of layer VI pyramidal cells without statistically significant difference between the PAG-positive and PAG-negative cells (Table 2). In six pyramidal cells, a long-duration depolarizing pulse evoked initial several spikes that were followed by a long pause of firings without large AHPs. Although these cells showed the frequency adaptation of initial spikes, they were, in Table 2, not counted as neurons displaying spike frequency adaptation. In most pyramidal cells, the "sag" potential, reportedly due to time-dependent anomalous rectification (Halliwell and Adams, 1982), was not prominent in response to injection of long-duration hyperpolarizing pulses. However, overall inward rectification (Fig. $\left.4 b_{2}, b_{3}\right)$, which was determined by measuring potential changes at the end of long hyperpolarizing pulses (arrowheads in Fig. $4 a_{2}, b_{2}$ ), was found in three PAG-positive and nine PAG-negative pyramidal cells ( $p<0.02$; Table 1 ).

In summary, PAG-positive and PAG-negative pyramidal cells in layer VI differed in many electric membrane propertics, cspecially in afterpotentials such as AHPs and DAPs. Thus, the electrical differences between the two groups of layer VI pyramidal cells support the chemical classification of the pyramidal cells based on PAG immunoreactivity.

\section{Cell bodies and dendrites of layer VI pyramidal cells}

Table 3 is the summary of the somatic and dendritic characteristics of layer VI pyramidal cells. The soma area of PAG-positive layer VI pyramidal cells was larger than that of PAG-negative ones $(p<0.05)$. No difference in the position of cell bodies within cortical thickness was found between PAG-positive and PAG-negative pyramidal cells. However, PAG-positive and PAG-negative pyramidal cells were distributed differently be- 


\section{Large fAHP}

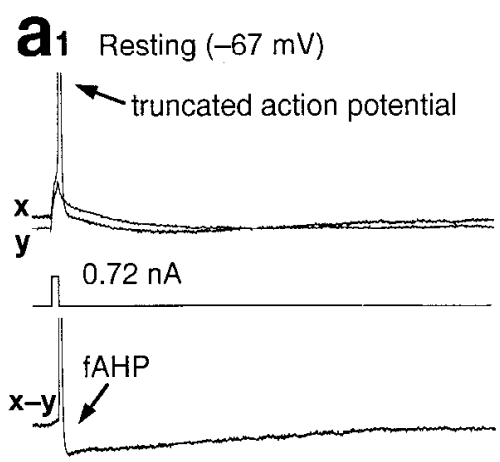

Q2 Depolarized (+0.13nA, $-58 \mathrm{mV})$

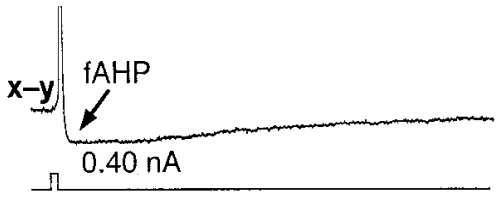

Q3 Hyperpolarized (-0.4 nA, $-91 \mathrm{mV})$

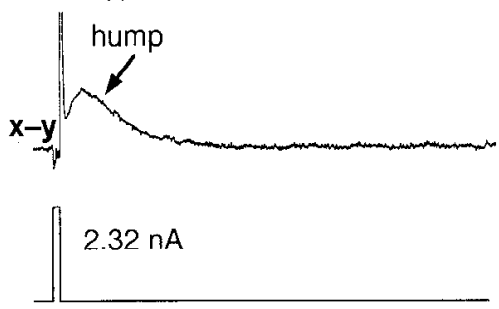

Small fAHP + mAHP

b1 Resting (-70 mV)

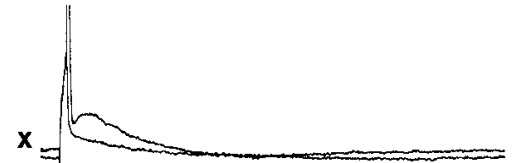

$\mathbf{y}^{-1}$

$1.2 \mathrm{nA}$

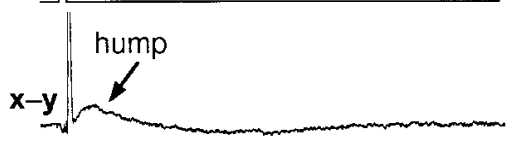

b2 Depolarized $(+0.2 n A,-60 \mathrm{mv})$

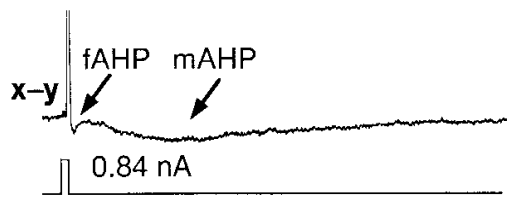

D3 Hyperpolarized (-0.4 nA, $-86 \mathrm{mV})$

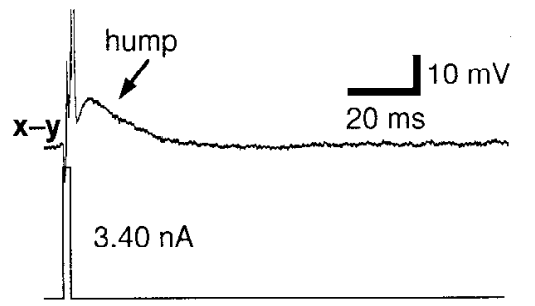

Figure 3. Afterpotentials in layer VI pyramidal cells. An action potential was evoked by injecting a threshold depolarizing current pulse of $2-10 \mathrm{msec}$ duration (trace $x$ ). The subthreshold response (trace $y$ ) evoked by the same current pulse from a slightly hyperpolarized level $(0.05-0.1 \mathrm{nA}$ negative from trace $\mathrm{x}$ ) was subtracted from trace $x$ to reveal aclive components in association with the action potential trace $x-y) . a_{1}-a_{3}$ and $b_{1}-b_{3}$ are the examples of two types of AHPs, large AAHP and small fAHP + mAHP, respectively. tween cortical areas; PAG-positive cells were found only in the SmI cortex (Par1 and FL-HL areas), while PAG-negative cells were found in the MsI and SmI cortices (Figs. 6, 7). This is unlikely to be due to a sampling bias, because many trials were made to get PAG-positive pyramidal cells in the MsI cortex. $\Lambda$ ctually, four spiny $P \Lambda G$-positive neurons were recovered in

Table 2. Electrophysiological properties of layer VIa pyramidal cells

$\begin{array}{lcll} & \begin{array}{l}\text { PAG } \\ \text { positive }\end{array} & \begin{array}{l}\text { PAG } \\ \text { negative }\end{array} & \begin{array}{l}p \\ \text { (Fisher test) }\end{array} \\ \text { Number of cells } & 12 & 11 & - \\ \text { fAHP peak alone } & 0 & 10 & \\ \text { fAHP and mAHP peaks } & 7 & 1 & <0.0001^{a} \\ \text { mAHP peak alone } & 5 & 0 & \\ \text { DAP } & 5 & 0 & 0.0037 \\ \text { Depolarizing "hump" } & 9 & 3 & 0.039 \\ \text { Initial doublet/triplet spikes } & 9 & 3 & 0.039 \\ \text { Rebound spikes } & 1 & 2 & 0.57 \\ \text { Spike frequency adaptation } & 8 & 9 & 0.47 \\ \text { Inward rectification } & 3 & 9 & 0.012 \\ & & & \end{array}$

Data are number of cases.

${ }^{a}$ fAHP peak alone compared with the combined group of fAHP and $\mathrm{mAHP}$ peaks and $\mathrm{mAHP}$ peak alone. layer VI of the MsI cortex, but they invariably had long descending dendrites entering the subcortical white matter. These neurons were therefore not classified into pyramidal cells in the present study. Since the PAG-positive nonpyramidal cells had a thick axon entering the subcortical white matter, they were considered to be projection ncurons as were pyramidal cells. During the trials to get PAG-positive pyramidal cells in and around the MsI cortex, two PAG-positive pyramidal cells were impaled in FL-HL area of Zilles (1985) just laterally to the MsI cortex (cells 1, 2 in Fig. 6), and one in Fr2 area just medially to the MsI cortex (not shown).

There seemed no clear difference in spine density on apical and basal dendrites between the two groups of pyramidal cells (Fig. 8). The apical dendrites of PAG-positive pyramidal cells were Imuch shorter than those of PAG-negative pyramidal cells $(p<0.01)$ although the thickness of apical dendrites showed no difference between the two groups (Table 3). Five of 12 PAGpositive pyramidal cells had the apical dendrites that ended in layer V, while all PAG-negative pyramidal cells extend the apical dendrites beyond layer V ( $p=0.037$ by the Fisher test; Figs. $6,7)$. On the contrary, basal dendrites and the side branches of apical dendrites were more developed in PAG-positive pyramidal cells than in PAG-negative cells (Figs. 6, 7). The horizontal stretch of basal-dendrite arborization was much wider in PAGpositive pyramidal cells than in PAG-negative cells $(p<0.001)$. 


\section{Q1 PAG(+) pyramidal cell}
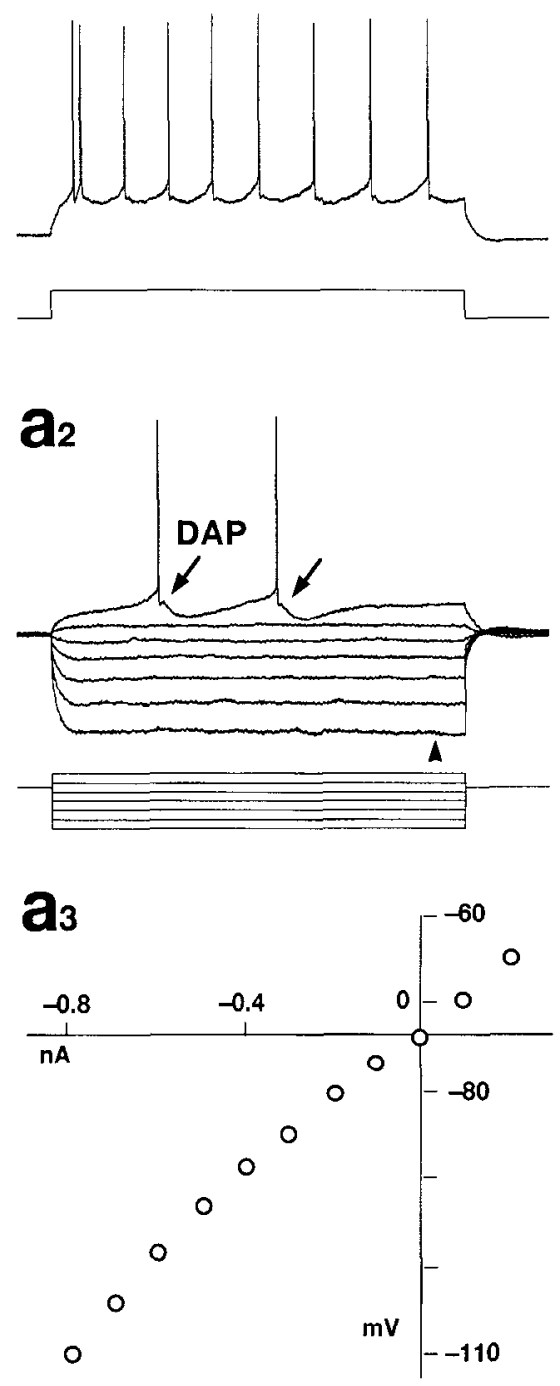

\section{b1 PAG( $\rightarrow$ pyramidal cell}
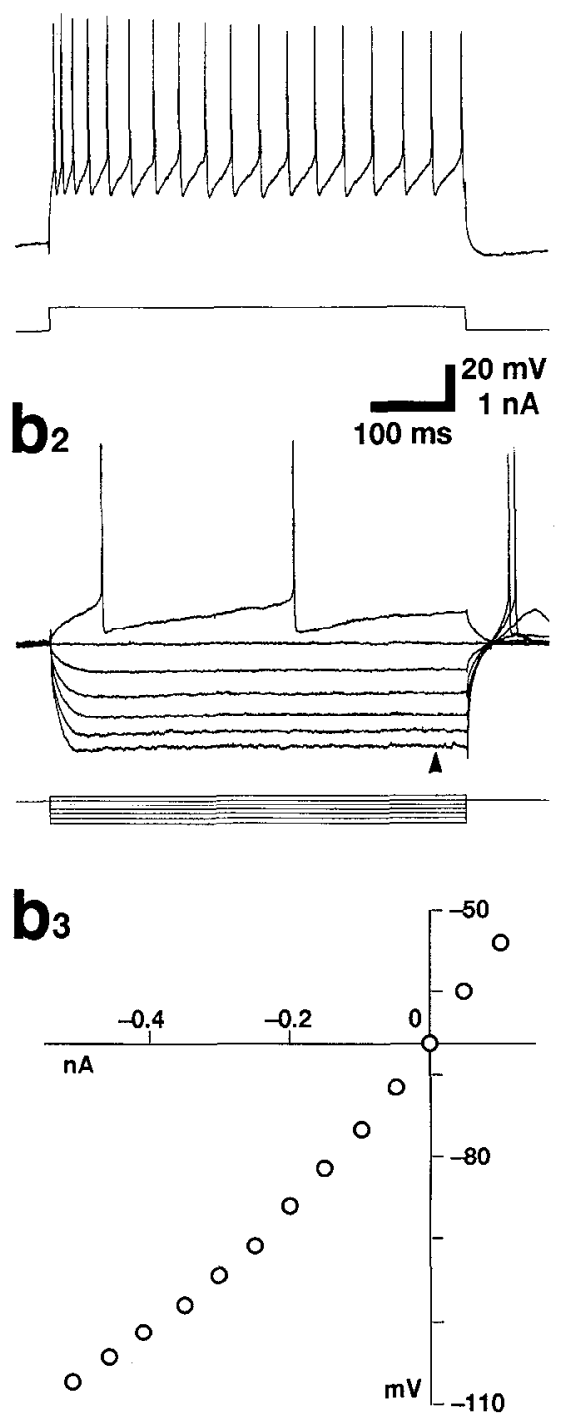

Figure 4. Responses of layer VI pyramidal cells evoked by long depolarizing and hyperpolarizing pulses. $a_{3}-a_{3}$ and $b_{1}-b_{3}$ are the examples of PAGpositive and PAG-negative pyramidal cells, respectively. Arrows in $a_{2}$ indicate DAPs. $a_{3}$ and $b_{3}$ show the currentvollage relationship measured at the end of $500 \mathrm{msec}$ current injection (indicated by arrowheads in $a_{2}$ and $b_{2}$ ).

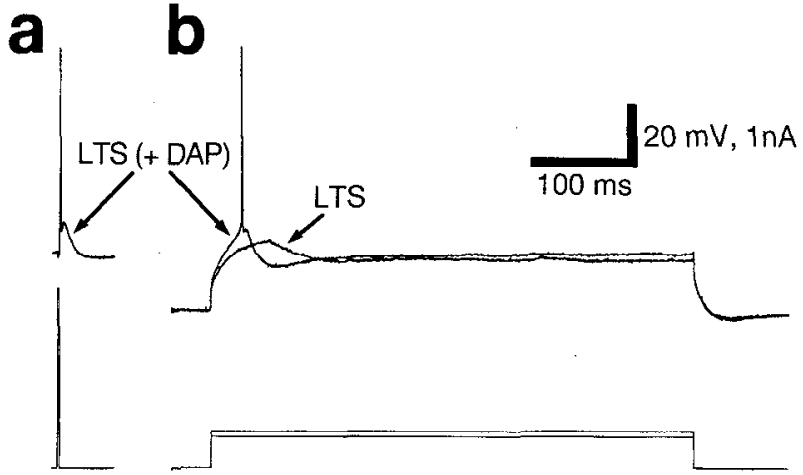

Figure 5. Slow depolarizing "humps" evoked by injecting short $(a)$ and long $(b)$ depolarizing current pulses. The hump is considered to consist of an LTS and/or a DAP.
Two PAG-positive pyramidal cells (ncurons 11, 12 in Fig. 6), which showed an fAHP and an mAHP of comparable depth, had a tall apical dendrite and less developed basal dendrites, as PAGnegative pyramidal cells did (Fig. 7). Neurons 8 and 9 in Figure 6 had sizable descending dendrites, but the dendrites never entered the subcortical white matter.

The results concerning the dendritic arborization were further supported by a Sholl analysis of dendrites (Sholl, 1956); the number of the intersections of dendrites with concentric circles around a cell hody was plotted against the radius of the circle, that is, distance from the center of the cell body (Fig. 9). Statistically significant differences between the two groups of layer VI pyramidal cells were observed at two sites, $80-160 \mu \mathrm{m}$ and 560-760 $\mu \mathrm{m}$ distant from the center of the cell body. At the former site, the number of the intersections of dendrites was larger in PAG-positive pyramidal cells than in PAG-negative cells, expressing the well-developed basal dendrites of PAGpositive cells. In contrast, the number of the intersections at the more distant site was smaller in PAG-positive pyramidal cells than in PAG-negative cells, mainly because apical dendrites were shorter in PAG-positive cells than in PAG-negative cells. 


\section{Table 3. Morphological properties of layer VIa pyramidal cells}

\begin{tabular}{lccl} 
& PAG positive & PAG negative & $p(U$ test $)$ \\
\hline $\begin{array}{l}\text { Number of cells } \\
\text { Soma area }\left(\mu \mathrm{m}^{2}\right)\end{array}$ & 12 & 11 & - \\
$\begin{array}{l}\text { Normalized depth of cell body } \\
\quad(\text { surface }=0, \text { white matter border }=1)\end{array}$ & $0.73 \pm 0.06$ & $0.74 \pm 0.07$ & 0.85 \\
$\begin{array}{l}\text { Height of apical dendrite }(\mu \mathrm{m}) \\
\text { Diameter of apical dendrite }\end{array}(\mu \mathrm{m})$ & $612 \pm 184$ & $823 \pm 104$ & 0.0031 \\
$\begin{array}{l}\text { Horizontal width of basal- } \\
\text { dendrite arborization }(\mu \mathrm{m})\end{array}$ & $1.25 \pm 0.51$ & $1.18 \pm 0.36$ & 1.0 \\
\hline
\end{tabular}

Data are mean \pm SD.

"Measured at $80 \mu \mathrm{m}$ from the center of the soma.

\section{Axons of layer VI pyramidal cells}

The axons of all biocytin-injected pyramidal cells in layer VI were reconstructed by camera lucida drawing. All the pyramidal cells had a main axon descending from the basal surface of the cell body, and all the main axons left for the subcortical white matter, giving off many local axon collaterals before leaving. The axonal arborizations of five PAG-positive and eight PAGnegative pyramidal cells are presented in Figures 10 and 11, respectively. In the other cells, the staining of axon collaterals was insufficient in intensity. There was an obvious difference in the local arborization of axon collaterals between the two groups of pyramidal cells. The axon collaterals of most PAG-positive pyramidal cells were widely distributed with a bias toward lower layers under the cell bodies (cells 4, 6, 7, 8 in Fig. 11). Only pyramidal cell 12 showed a vertically oriented arborization of axon collaterals above the cell body (Fig. 10). It should be noted that this cell 12 had a long apical dendrite (Fig. 6) and showed an $\mathrm{AAHP}$ and an mAHP of comparable depth.

All PAG-negative pyramidal cells, similarly to cell 12 in Figure 10, expressed vertically arborized axon collaterals along the apical dendrites (Fig. 11). The horizontal width of axon collateral clusters was $600 \mu \mathrm{m}$ or less; this was much narrower compared with cells $4,6,7$, and 8 in Figure 10. The relative poverty of axon collaterals in the PAG-negative cells did not seem to be ascribable to insufficient staining, because the axon collaterals of some neurons, such as cells. 21 and 23, were not abundant in spite of the very intense labeling.

\section{Discussion}

The present results suggest that pyramidal cells in layer VIa of rat SmI and MsI cortices are separated into two groups (Fig. 12). One group of pyramidal cells is characterized by expressing PAG immunoreactivity, showing no or a small fAHP, and possessing a short apical dendrite and well developed basal dendrites with horizontally spread axon collaterals. The other group of pyramidal cells is distinguished by lacking PAG immunoreactivity, showing a prominent $\mathrm{AAHP}$, and having a long apical dendrite and less developed basal dendrites with vertically localized axon collaterals. The presence of PAG-positive pyramidal cells (cells 11,12 in Figs. 6, 10), which resemble PAGnegative pyramidal cells in electrical and morphological properties, further suggests that PAG-positive pyramidal cells in layer VI are not a homogeneous group.

\section{Technical aspects}

The presence of PAG-immunonegative pyramidal cells was unexpected at the beginning of the present study. Slice preparation might spuriously suppress PAG immunoreactivity. The number of GABA-immunoreactive neurons in cortical slices has been reported to decrease as a function of the incubation time of the slices (Chun and Artola, 1989). This is one of the reasons why we used CB and PV immunoreactivities to identify GABAergic neurons in the present study. However, since PAG is not a transmitter but a synthesizing enzyme of transmitter glutamate, it is unlikely that PAG in cortical slices is decreased drastically during incubation for scveral hours (Szcrb and O'Regan, 1984; Kapetanovic et al., 1993). Furthermore, the in vivo presence of PAG-immunonegative, non-GABAergic neurons was confirmed by detecting many PAG-negative and $\mathrm{CB} / \mathrm{PV}$-negative neurons in deep cortical layers using perfusion-fixed brains (Fig. 2). PAG immunoreactivity might be suppressed by the inaccessibility of the antibody to the antigen. However, the use of weak fixation (3\% formaldehyde and $0.003 \%$ glutaraldehyde) and thin sections (30 $\mu \mathrm{m}$ thick) appeared to make the tissue sufficiently penetrable to the applied antibodies, since many neurons around the intracellularly labeled cells were immunostained for PAG and CB/ PV (Fig. 1). Finally, if PAG immunoreactivity had been artificially suppressed by experimental procedures, such as slice preparation, biocytin injection and fixation, PAG-negative cells would have been distributed at random in the two electrophysiologically and morphologically differentiated groups of pyramidal cells. This was not true in the present study. Thus, PAG immunonegative pyramidal cells are considered really to exist in the deep layers of the cerebral neocortex, although the content of PAG in some pyramidal cells might be too low to be detected by the present method.

The reconstruction of intracellularly labeled neurons, particularly that of axon collaterals, is often difficult in the slice method. In the rostrocaudal direction, the reconstruction was limited up to $500 \mu \mathrm{m}$ and would therefore be incomplete. To reduce this limitation, we abandoned the intracellularly impaled neurons which were within $100 \mu \mathrm{m}$ from the section surface of the slices. The vast majority of the dendrites were traced through several sections, but not up to the cut-end sections of the slice, indicating that the dendrites terminated within the slice. The reconstruction of the soma and dendrites was hence considered nearly complete.

\section{Spike afterpotentials}

The most evident difference of electrical properties between the two groups of layer VI pyramidal cells was found in spike afterpotentials. Most PAG-positive pyramidal cells examined in the present study showed no or a small fAHP, whereas most PAG-negative cells displayed a prominent fAHP. Currents un- 


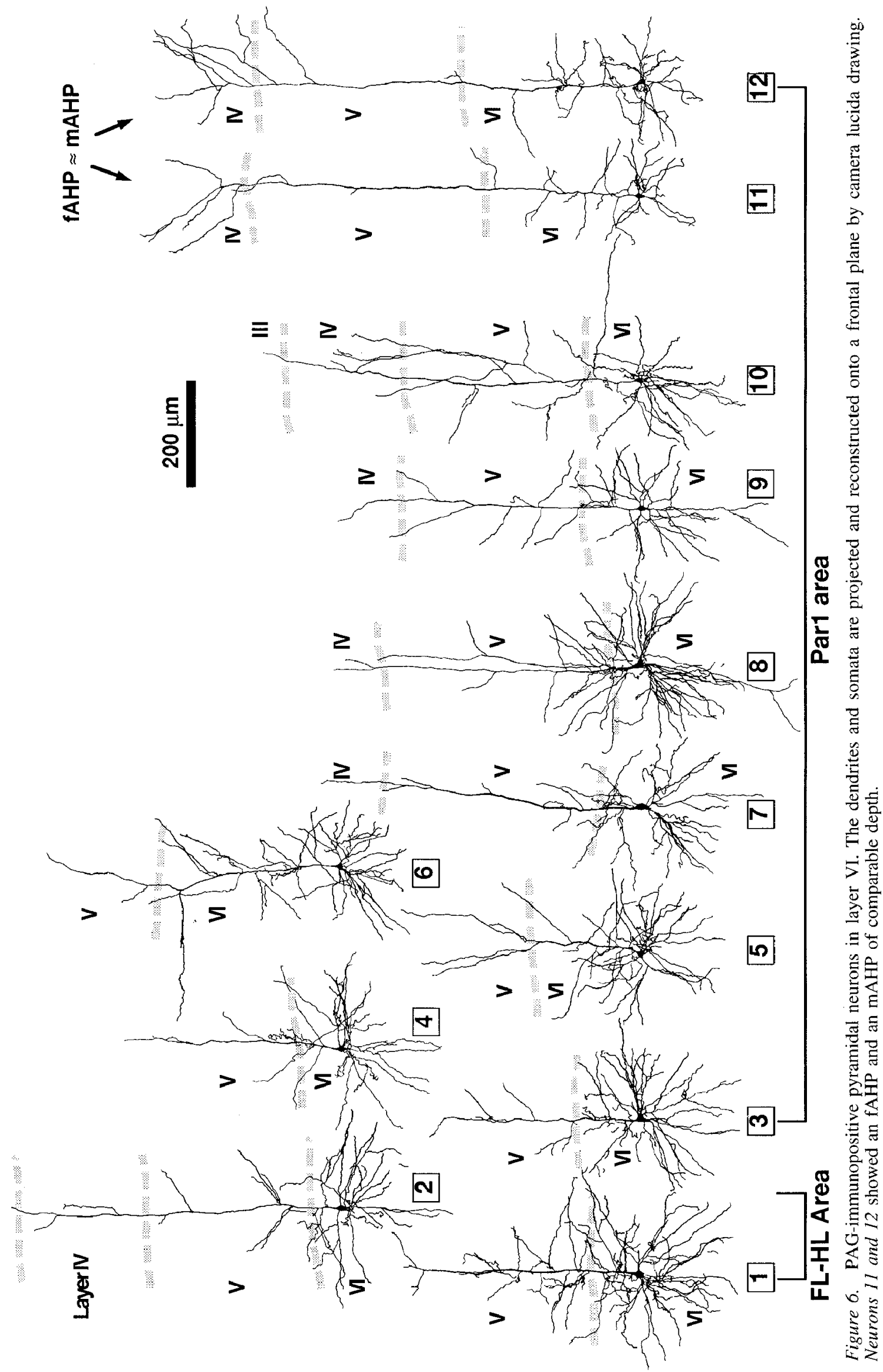




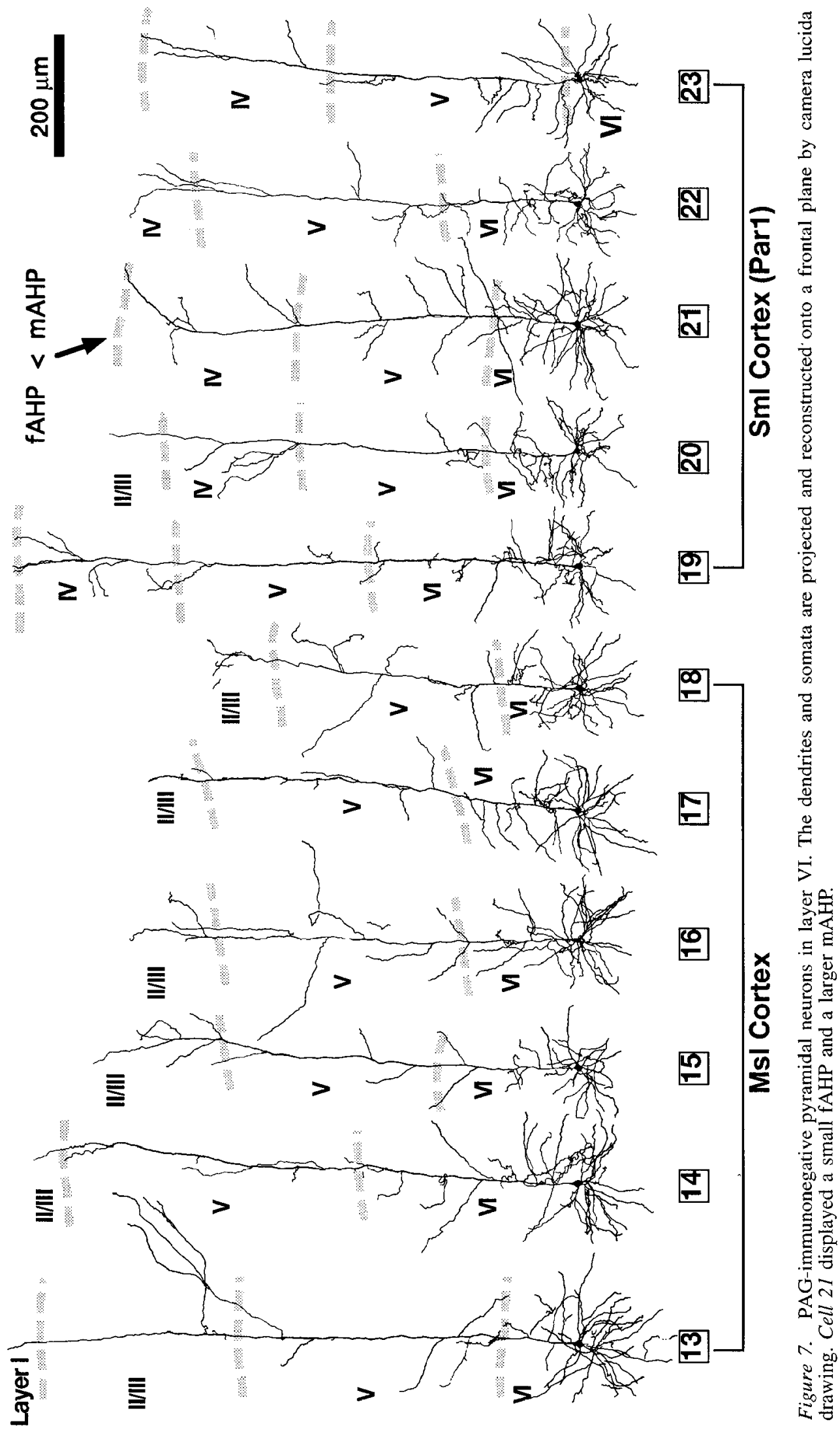



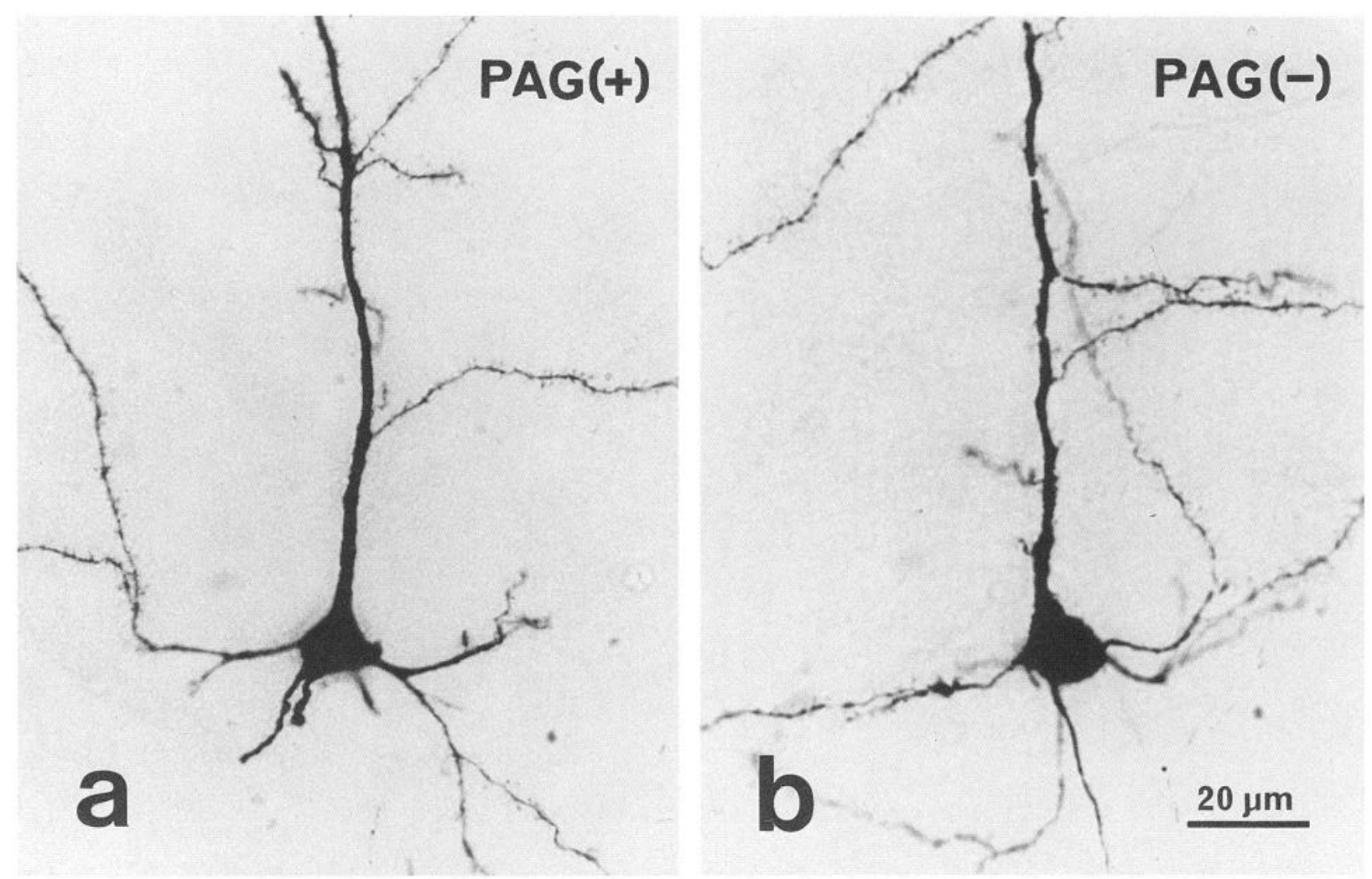

Figure 8. The cell bodies and dendrites of pyramidal neurons in layer VI. PAG-immunopositive ( $a$; cell 6 in Fig. 6) and PAG-immunonegative pyramidal cells ( $b$; cell 20 in Fig. 7 ) were stained by the ABC method.

derlying the fAHP have been considered to include the transient potassium current, fast calcium-activated potassium current and delayed rectifier (for review, see McCormick, 1990). The occurrence of no or a small fAHP in PAG-positive pyramidal cells may be due to (1) small fast potassium currents, and/or (2) depolarizing currents that counteract with the fast hyperpolarizing potassium currents. The latter is likely to be the case, because DAPs were observed only in PAG-positive pyramidal cells. In the present study, the DAP was recognized as a depolarizing notch superimposed on the fAHP (Fig. $4 a_{2}$ ). According to this

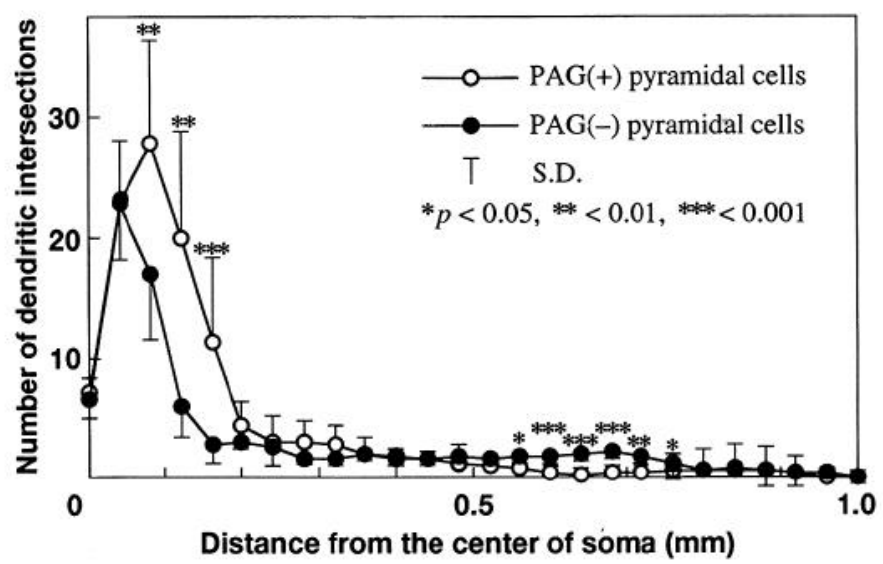

Figure 9. The dendritic arborization of layer VI pyramidal neurons is analyzed by Sholl's method. The number of dendritic intersections with concentric circles around a soma is plotted at $40 \mu \mathrm{m}$ steps against distance from the center of the soma, that is, the radius of the circle. Statistical significance was determined by the two-tailed $U$ test. definition, clear DAPs were found only in five PAG-positive pyramidal cells. However, if the DAP is small and cancelled out with fast hyperpolarizing potassium currents, the DAP may not be identified as was defined in the present study.

Kang and Kayano (1994) reported that layer VI pyramidal cells in the cat cerebral cortex were separated into two groups on the basis of the presence or absence of DAPs. In pyramidal cells showing DAPs, doublet/triplet spikes in response to a longduration depolarizing pulse, which initially occurred only at the onset of a pulse, became repetitive in a pulse after long-duration pulses were injected at $1 \mathrm{~Hz}$ for $30-60 \mathrm{sec}$. In the present study, DAPs were observed only in PAG-positive pyramidal cells. Thus, PAG-positive pyramidal cells showing DAPs and/or small fAHPs may change the membrane response properties by the history of inputs. This suggests a functional difference in relation to the plasticity of membrane properties between PAG-positive and PAG-negative pyramidal cells in layer VI.

\section{Functional implication of morphological difference}

The apical dendrites of most PAG-positive pyramidal cells in layer VI were limited within layer V or IV. In contrast, those of many PAG-negative cells were extended into layer II/III. These results indicate that the input flow of information differs between the two groups of layer VI pyramidal cells. PAG-negative pyramidal cells collect information from both the superficial and deep layers of the cerebral cortex, whereas PAG-positive pyramidal cells mainly pick up information from the deep layers. Furthermore, PAG-positive pyramidal cells appeared to specialize in receiving inputs from the deep layers, because the arborization of basal dendrites was more developed in PAG-positive cells than in PAG-negative cells. 


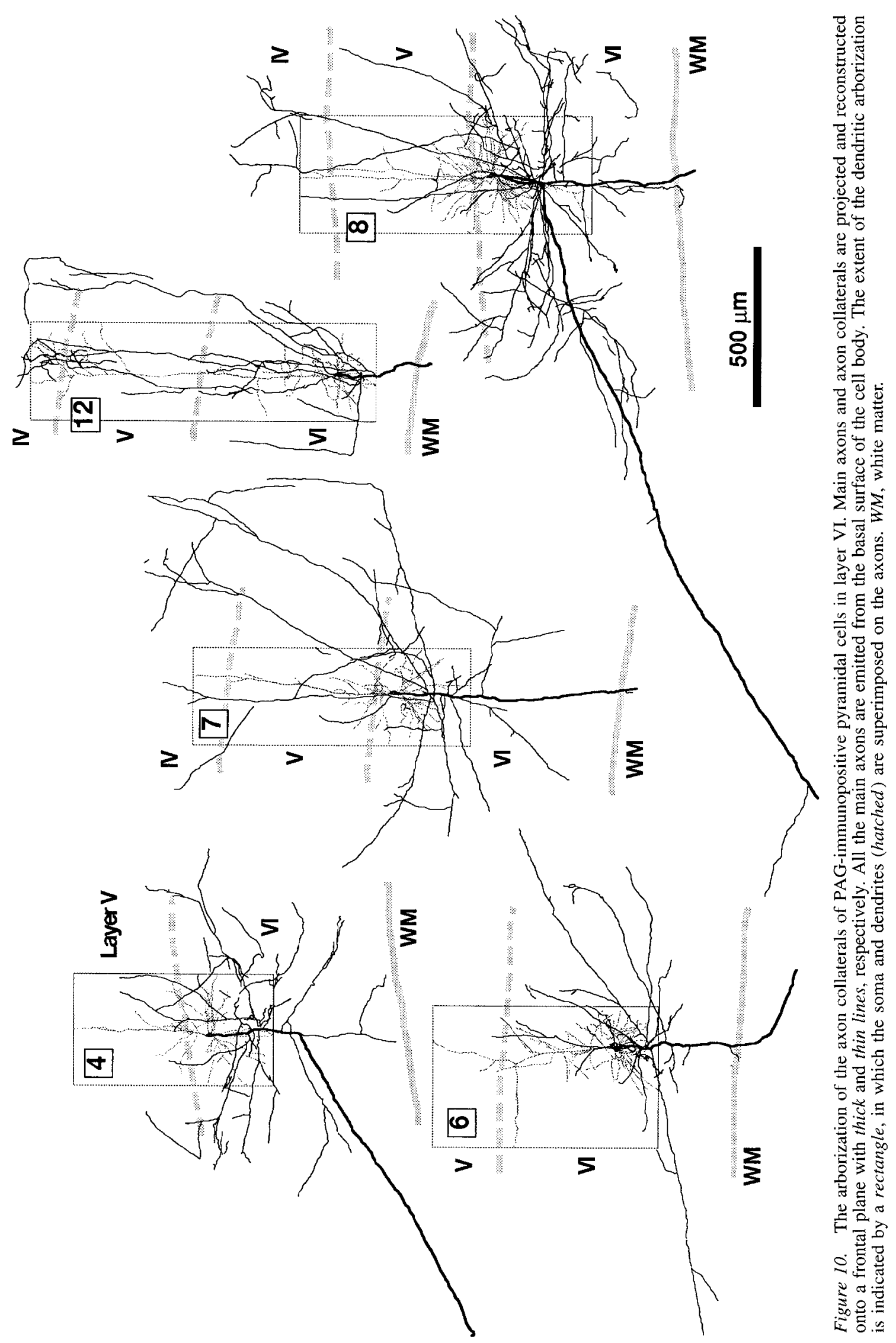




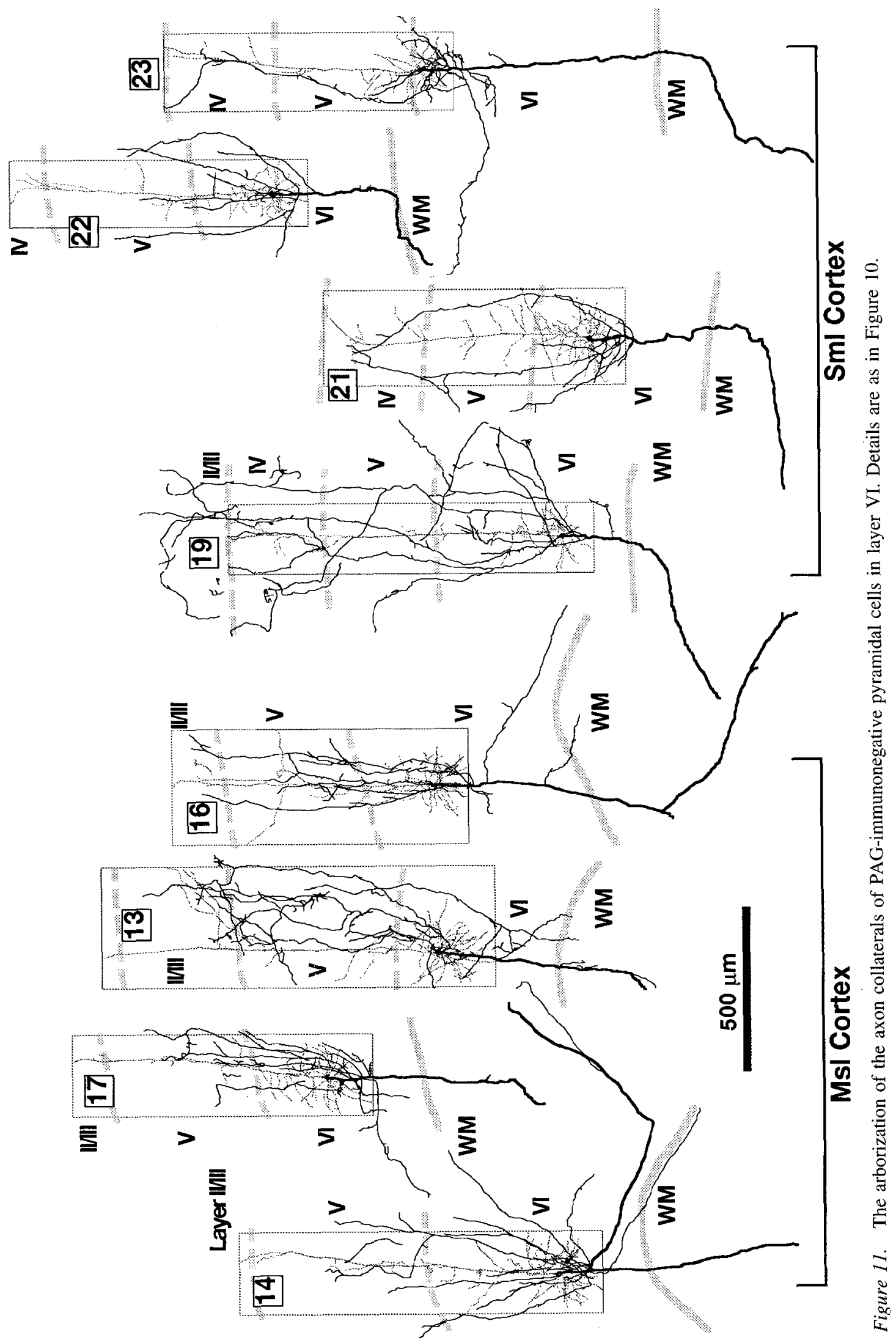




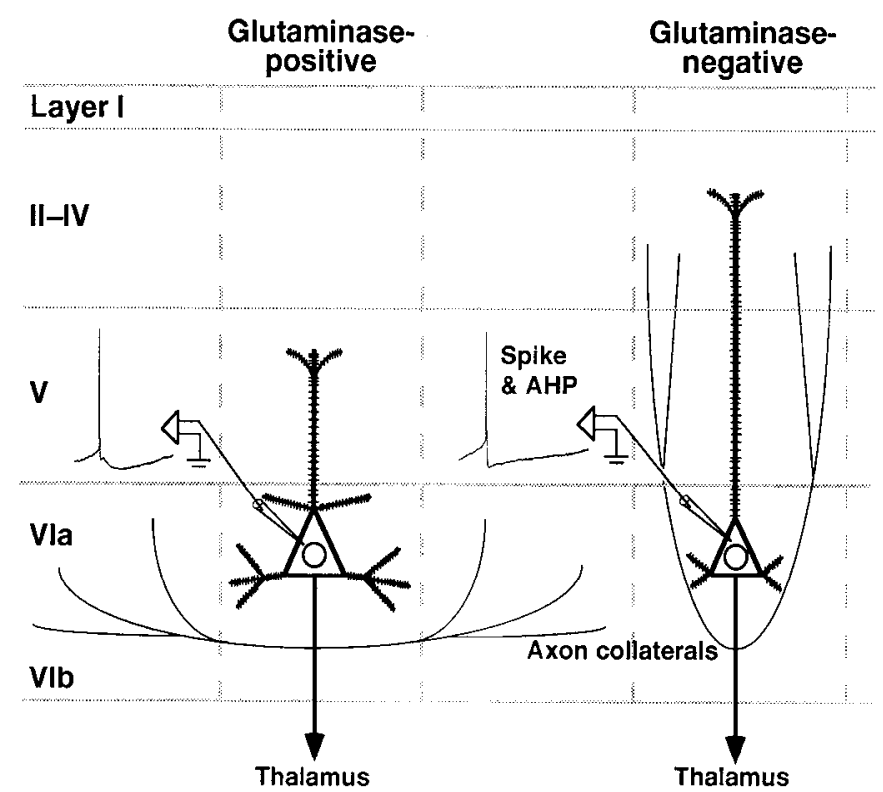

Figure 12. Summary diagram of two types of pyramidal neurons in layer VI of the cerebral cortex. Vertical dashed lines indicate the cortical columnar structure, such as barrels. For details, see Discussion.

The difference of axon collateral arborization between the two groups of layer VI pyramidal cells indicates that the intracortical targets of outputs from the two groups also differ. The columnar organization has been reported in the cerebral cortex of many mammals including rodents (for review, see Jones, 1981). In the SmI barrel cortex of the rat brain, the cortical columnar structure (barrel) has a diameter of $250-500 \mu \mathrm{m}$ (Welker and Woolsey, 1974; Chmielowska et al., 1989). The horizontal spread of the vertically oriented collateral arborization of PAG-negative pyramidal cells was equal to or somewhat larger than that of the cortical barrel (Fig. 9). In contrast, PAG-positive pyramidal cells showed more widely spread arborization of axon collaterals (Fig. 8). In the cortical barrel of the SmI cortex, laminar differences in the information processing of somatosensory inputs have been reported (Lamour et al., 1983; Simons, 1985; Chapin, 1986). The present results hence suggest that PAG-negative layer VI pyramidal cells collect various kinds of information from different layers and send it back to their own barrel, whereas PAGpositive pyramidal cells receive information from the deep layers and spread it to the neighboring cortical barrels (Fig. 12).

\section{Corticothalamic projection and transmitters}

Many pyramidal neurons in layer VI have been reported to send axons to thalamic nuclei (Gilbert and Kelly, 1975; Jacobson and Trojanowski, 1975; Lund et al., 1975; Wise and Jones, 1977; Gilbert and Wiesel, 1981; Katz, 1987). From the present results, it is not determined which kind of pyramidal cell, PAG-positive or PAG-negative one, sends axons to the thalamus. Some pyramidal cells in layer VI have been reported to send axons to the claustrum (LeVay and Sherk, 1981; Katz, 1987) and to other cortical areas (for review, see Jones, 1984; Rosenquist, 1985). However, the MsI cortex of rats and mice does not seem to send projection fibers to the claustrum (Sherk, 1986). In layer VI of rat MsI and SmI areas, corticocortical neurons are much less densely distributed than corticothalamic neurons (Jacobson and Trojanowski, 1974, 1975; Wisc, 1975; Wisc and Jones, 1976, 1977; Giuffrida and Rustioni, 1988, 1989). Furthermore, in our preliminary study using a retrograde fluorescent tracer, tetramethylrhodamine-conjugated dextran amine, many corticothalamic projection neurons in layer VI of the SmI and MsI cortices showed immunofluorescence for PAG, but some corticothalamic neurons displayed no PAG immunofluorescence (Kaneko et al., unpublished observation). Thus, both PAG-positive and PAGnegative pyramidal cells are considered to send axons to the thalamic nuclei.

Giuffrida and Rustioni (1988) reported, in a combined analysis by retrograde labeling and immunocytochemistry, that 54 $60 \%$ and $55-60 \%$ of corticothalamic neurons in the SmI cortex contained immunoreactivity for aspartate and glutamate, respectively, and that, by double immunostaining, $89 \%$ of corticothalamic neurons showed immunoreactivity for aspartate and/or glutamate. Their results suggest that $29-34 \%$ of corticothalamic projection neurons are nonglutamatergic, presumably aspartatergic. In the present study, $29 \%$ of layer VI pyramidal neurons in the SmI cortex were immunonegative for PAG. These PAGnegative pyramidal neurons might use aspartate as their transmitter, although PAG is not a definitive marker for glutamatergic neurons. Thus, the thalamic nuclei are considered to receive not only glutamatergic but nonglutamatergic, possibly aspartatergic, fibers from the cerebral cortex. Cortical neurons may also receive both kinds of inputs from layer VI pyramidal cells through the intracortical axon collaterals. Since thalamic relay neurons express a metabotropic glutamate receptor that differently responds to glutamate and aspartate (Masu et al., 1991; Martin et al., 1992; McCormick and von Krosigk, 1992; Shigemoto et al., 1992), glutamatergic and nonglutamatergic corticothalamic neurons might have different effects on thalamic neurons.

\section{References}

Akiyama H, Kaneko T, Mizuno N, McGeer PL (1990) Distribution of phosphate-activated glutaminase in the human cerebral cortex. J Comp Neurol 297:239-252.

Aoki C, Kaneko T, Starr A, Pickel VM (1991) Identification of mitochondrial and nonmitochondrial glutaminase within select neurons and glia of rat forebrain by electron microscopic immunocytochemistry. J Neurosci Res 28:531-548.

Bradford HF, Ward HK, Thomas AJ (1978) Glutamine-a major substrate for nerve endings. J Neurochem 30:1453-1459.

Bradford HF, Ward HK, Foley P (1989) Glutaminase inhibition and the release of neurotransmitter glutamate from synaptosomes. Brain Res 476:29-34.

Celio MR (1986) Parvalbumin in most $\gamma$-aminobutyric acid-containing neurons of the rat cerebral cortex. Science 231:995-997.

Chapin JK (1986) Laminar differences in sizes, shapes, and response profiles of cutaneous receptive field in the rat SI cortex. Exp Brain Res 62:549-559.

Chmielowska J, Carvell GE, Simons DJ (1989) Spatial organization of thalamocortical and corticothalamic projection systems in the rat $\mathrm{SmI}$ barrel cortex. J Comp Neurol 285:325-338.

Chun MH, Artola A (1989) GABA-like activity in in vivo slices of the rat visual cortex: immunocytochemistry and electrophysiology. Brain Res 494:401-406.

Demeulemeester H, Vandesande F, Orban GA, Brandon C, Venderhaeghen JJ (1988) Heterogeneity of GABAergic cells in cat visual cortex. J Neurosci 8:988-1000.

Demeulemeester H, Vandesande F, Orban GA, Heizmann CW, Pochet $R$ (1989) Calbindin D $28-K$ and parvalbumin immunoreactivity is confined to two separate neuronal subpopulations in the cat visual cortex, whereas partial coexistence is shown in the dorsal lateral geniculate nucleus. Neurosci Lett 99:6-11.

Donoghue JP, Wise SP (1982) The motor cortex of the rat: cytoarchitecture and microstimulation mapping. J Comp Neurol 212:76-88.

Donoghue JP, Wenthold RJ, Altschuler RA (1985) Localization of glutaminase-like and aspartate aminotransferase-like immunoreactivity in neurons of cerebral neocortex. J Neurosci 5:2597-2608. 
Fuxc K, Hökfelt T, Said SI, Mutt V (1977) Vasoactive intestinal polypeptide and the nervous system: immunohistochemical evidence for localization in central and peripheral neurons, particularly intracortical neurons of the cerebral cortex. Neurosci Lett 5:241-246.

Gilbert CD, Kelly JP (1975) The projections of cells in different layers of the cat's visual cortex. J Comp Neurol 163:81-106.

Gilbert CD, Wiesel TN (1981) Laminar specialization and intracortical connections in cat primary visual cortex. In: The organization of the cerebral cortex (Schmitt FO, Worden FG, Adelman G, Dennis SG, eds), pp 163-191. Cambridge, MA: MIT Press.

Giuffrida R, Rustioni A (1988) Glutamate and aspartate immunoreactivity in corticothalamic neurons of rats. In: Cellular thalamic mechanisms (Bentivoglio M, Spreafico R, eds), pp 311-320. Amsterdam: Elsevier.

Giuffrida K, Rustioni A (1989) Glutamate and aspartate immunoreactivity in cortico-cortical neurons of the sensorimotor cortex of rats. Exp Brain Res 74:41-46.

Halliwell JV, Adams PR (1982) Voltage-clamp analysis of muscarinic excitation in hippocampal neurons. Brain Res 250:71-92.

Hamberger AC, Chiang GH, Nylén ES, Scheff SW, Cotman CW (1979a) Glutamate as a CNS transmitter. I. Evaluation of glucose and glutamine as precursors for the synthesis of preferentially released glutamate. Brain Res 168:513-530.

Hamberger AC, Chiang GH, Sandoval E, Cotman CW (1979b) Glutamate as a CNS transmitter. II. Regulation of synthesis in the releasable pool. Brain Res 168:531-541.

Hendry SHC, Jones EG, Emson PC, Lawson DEM, Heizmann CW, Streit P (1989) Two classes of cortical GABA neurons defined by differential calcium binding protein immunoreactivities. Exp Brain Res 76:467-472.

Jacobowitz DM, Winsky L (1991) Immunocytochemical localization of calretinin in the forebrain of the rat. J Comp Neurol 304:198-218.

Jacobson S, Trojanowski JQ (1974) The cells of origin of the corpus callosun in rat, cal and rhesus monkey. Brain Res 74:149-155.

Jacobson S, Trojanowski JQ (1975) Corticothalamic neurons and thalamocortical fields: an investigation in rat using horseradish peroxidase and autoradiography. Brain Res 85:385-401.

Jahnsen H, Llinás R (1984a) Electrophysiological properties of guineapig thalamic neurons: an in vitro study. J Physiol (Lond) 349:205226.

Jahnsen H, Llinás R (1984b) Ionic basis for the electroresponsiveness and oscillatory properties of guinea-pig thalamic neurones in vitro. $\mathrm{J}$ Physiol (Lond) 349:227-247.

Jones EG (1981) Anatomy of cerebral cortex: columnar input-output organization. In: The organization of the cerebral cortex (Schmitt FO, Worden FG, Adelman G, Dennis SG, eds), pp 199-235. Cambridge, MA: MIT Press

Jones EG (1984) Laminar distribution of cortical efferent cells. In: Cerebral cortex, Vol 1, Cellular components of the cerebral cortex (Peters A, Jones EG, eds), pp 521-553. New York: Plenum.

Kaneko T, Mizuno N (1988) Immunohistochemical study of glutaminase-containing neurons in the cerebral cortex and thalamus of the rat. J Comp Neurol 267:590-602.

Kaneko T, Mizuno N (1994) Glutamate-synthesizing enzymes in GABAergic neurons of the neocortex: a double immunofluorescence study in the rat. Neuroscience 61:839-849.

Kaneko T, Urade Y, Watanabe Y, Mizuno N (1987) Production, characterization; and immunohistochemical application of monoclonal antibodies to glutaminase purified from rat brain. J Neurosci 7:302309.

Kaneko T, Urade Y, Mizuno N (1988) Correlation hetween immunochemical characteristics and immunohistochemical applicability of nine lines of monoclonal antibodies against rat brain glutaminase. J Histochem Cytochem 36:997-1004.

Kaneko T, Itoh K, Shigemoto R, Mizuno N (1989) Glutaminase-like immunoreactivity in the lower brainstem and cerebellum of the adult rat. Neuroscience 32:79-98.

Kaneko T, Nakaya Y, Mizuno N (1992) Paucity of glutaminase-immunoreactive nonpyramidal neurons in the rat cerebral cortex. J Comp Neurol 322:181-190.

Kang Y, Kayano F (1994) Electrophysiological and morphological characteristics of layer VI pyramidal cells in the cat motor cortex. $\mathbf{J}$ Neurophysiol 72:578-591.

Kapetanovic IM, Yonekawa WD, Kupferberg HJ (1993) Time-related loss of glutamine from hippocampal slices and concomitant changes in neurotransmitter amino acids. J Neurochem 61:865-872.

Katz LC (1987) Local circuitry of identified projection neurons in cat visual cortex brain slices. J Neurosci 7:1223-1249.

Kubota Y, Hattori R, Yui Y (1994) Three distinct subpopulations of GABAergic neurons in rat frontal agranular cortex. Brain Res 649: 159-173.

Lamour Y, Guilbaud G, Willer JC (1983) Rat somatosensory (SmI) cortex: II. Laminar and columnar organization of noxious and nonnoxious inputs. Exp Brain Res 49:46-54.

LeVay S, Sherk H (1981) The visual claustrum of the cat. I. Structure and connections. J Neurosci 1:956-980.

Lorente de Nó R (1949) Cerebral cortex: architecture, intracortical connections, motor projections. In: Physiology of the nervous system, 3d ed (Fulton JF, ed), pp 288-330. London: Oxford UP.

Lund JS, Lund RD, Hendrickson AE, Bunt AH, Fuchs AF (1975) The origin of efferent pathways from the primary visual cortex, area 17 , of the macaque monkey as shown by retrograde transport of horseradish peroxidase. J Comp Neurol 164:287-304.

Lund JS, Henry GH, MacQueen CL, Harvey AR (1979) Anatomical organization of the primary visual cortex (area 17) of the cat. A comparison with area 17 of the macaque monkey. J Comp Neurol 184:599-618.

Martin LJ, Blackstone CD, Huganir RL, Price DL (1992) Cellular localization of a metabotropic glutamate receptor in rat brain. Neuron $9: 259-270$.

Masu M, Tanabe Y, Tsuchida K, Shigemoto R, Nakanishi S (1991) Sequence and expression of a metabotropic glutamate receptor. $\mathrm{Na}$ ture 349:760-765.

McCormick DA (1990) Membrane properties and neurotransmitter actions. In: The synaptic organization of the brain, $3 \mathrm{~d}$ ed (Shepherd GM, ed), pp 32-66. New York: Oxford UP.

McCormick DA (1992) Neurotransmitter actions in the thalamus and cerebral cortex and their role in neuromodulation of thalamocortical activity. Prog Neurobiol 39:337-388.

McCormick DA, von Krosigk M (1992) Corticothalamic activation modulates thalamic firing through glutamate 'metabotropic' receptors. Proc Natl Acad Sci USA 89:2774-2778.

McCormick DA, Connors BW, Lighthall JW, Prince DA (1985) Comparative electrophysiology of pyramidal and sparsely spiny stellate neurons of the neocortex. J Neurophysiol 54:782-806.

Reubi JC (1980) Comparative study of the release of glutamate and GABA, newly synthesized from glutamine, in various regions of the central nervous system. Neuroscience 5:2145-2150.

Reubi JC, Cuénod M (1979) Glutamate release in vitro from corticostriatal terminals. Brain Res 176:185-188.

Reubi J-C, van der Berg C, Cuénod M (1978) Glutamine as precursor for the GABA and glutamate transmitter pools. Neurosci Lett 10: 171-174.

Rosenquist AC (1985) Connections of visual cortical areas in the cat In: Cerebral cortex, Vol 3, Visual cortex (Peters A, Jones EG, eds), pp 81-117. New York: Plenum.

Schwindt PC, Spain WJ, Fochring RC, Stafstrom CE, Chubb MC, Crill WE (1988) Multiple Potassium conductances and their functions from cat sensorimotor cortex in vitro. J Neurophysiol 59:424-449.

Sherk H (1986) The claustrum and the cerebral cortex. In: Cerebral cortex, Vol 5, Sensory-motor areas and aspects of cortical connectivity (Jones EG, Peters A, eds), pp 467-499. New York: Plenum.

Shigemoto R, Nakanishi S, Mizuno N (1992) Distribution of the messenger RNA for a metabotropic glutamate receptor (mGluR 1 ) in the central nervous system-an in situ hybridization study in adult and developing rat. J Comp Neurol 322:121-135.

Sholl DA (1956) The quantification of neuronal connectivity. In: The organization of the cerebral cortex (Sholl DA, ed), pp 43-63. London: Methuen.

Siegel S (1956) Nonparametric statistics for the behavioral sciences. Tokyo: McGraw-Hill Kogakusha.

Simons DJ (1985) Temporal and spatial integration in the rat SI vibrissa cortex. J Neurophysiol 54:615-635.

Sternberger LA (1979) Immunocytochemistry, 2d ed. New York: Wiley.

Swanson LW (1992) Brain maps: structure of the rat brain. Amsterdam: Elsevier.

Szerb JC, O'Regan PA (1984) Glutamine enhances glutamate release 
in preference to gamma-aminobutyrate release in hippocampal slices. Can J Physiol Pharmacol 62:919-923.

Thanki CM, Sugden D, Thomas AJ, Bradford HF (1983) In vivo release from cerebral cortex of $\left[{ }^{14} \mathrm{C}\right]$ glutamate synthesized from [U${ }^{14}$ Clglutamine. J Neurochem 41:611-617.

Tömböl T (1984) Layer VI cells. In: Cerebral cortex, Vol 1, Cellular components of the cerebral cortex (Peters A, Jones EG, eds), pp 479519. New York: Plenum.

Van Brederode JFM, Mulligan KA, Hendrickson AE (1990) Calciumbinding proteins as markers for subpopulations of GABAergic neurons in monkey striate cortex. J Comp Neurol 298:1-22.

Van Brederode JFM, Helliesen MK, Hendrickson AE (1991) Distribution of the calcium-binding proteins parvalbumin and calbindinD28k in the sensorimotor cortex of the rat. Neuroscience 44:157171 .

Ward HK, Thanki CM, Bradford HF (1983) Glutamine and glucose as precursors of transmitter amino acids: ex vivo studies. J Neurochem 40:855-860.

Welker C, Woolsey TA (1974) Structure of layer IV in the somatosensory neocortex of the rat: description and comparison with the mouse. J Comp Neurol 158:437-454.

Wise SP (1975) The laminar organization of certain afferent and efferent fiber systems in the rat somatosensory cortex. Brain Res 90: $139-142$.

Wise SP, Jones EG (1976) The organization and postnatal development of the commissural projection of the rat somatic sensory cortex. J Comp Neurol 168:313-344.

Wise SP, Jones EG (1977) Cells of origin and terminal distribution of descending projections of the rat somatic sensory cortex. J Comp Neurol 175:129-158.

Zilles K (1985) The cortex of the rat. A stereotaxic atlas. Berlin: Springer. 